\title{
ЗАСТОСУВАННЯ АПАРАТНО-ПРОГРАМНИХ КОМПЛЕКСІВ В РЕАБІЛІТАЦІЇ ХВОРИХ 3 ВЕРТЕБРОГЕНИМИ ЗАХВОРЮВАННЯМИ
}

\author{
О. А. Панченко, С. М. Радченко, В. Г. Антонов, А. В. Зарубайко \\ ДЗ "Науково-практичний медичний реабілітаційно-діагностичний центр мОз України"
}

\begin{abstract}
Розглянуто сучасні аспекти реабілітації хворих із патологією опорно-рухової системи із застосуванням апаратнопрограмних комплексів. Проаналізовано отримані результати використання реабілітаційних програм із застосуванням кінезотерапії у хворих із вертеброгенними захворюваннями. Зроблено висновок про ефективність комплексів даного класу та рекомендовано більш широке їх застосування.
\end{abstract}

Ключові слова: реабілітація, кінезотерапія, інформатизація, реабілітаційне обладнання, апаратно-програмний комплекс.

\section{ПРИМЕНЕНИЕ АППАРАТНО-ПРОГРАМНЫХ КОМПЛЕКСОВ С ОБРАТНОЙ СВЯЗЬЮ В РЕАБИЛИТАЦИИ БОЛЬНЫХ С ВЕРТЕБРОГЕННЫМИ ЗАБОЛЕВАНИЯМИ}

\author{
О. А. Панченко, С. М. Радченко, В. Г. Антонов, А. В. Зарубайко \\ ГУ "Научно-практический медицинский реабилитационно-диагностический центр \\ МЗ Украины"
}

\begin{abstract}
Рассмотрены современные аспекты реабилитации больных с патологией опорно-двигательной системы с использованием аппаратно-программных комплексов. Проанализированы полученные результаты применения реабилитационных программ с использованием кинезотерапии у больных с вертеброгенной патологией. Сделан вывод об эффективности комплексов данного класса и рекомендовано более широкое их использование.
\end{abstract}

Ключевые слова: реабилитация, кинезотерапия, информатизация, реабилитационное оборудование, аппаратно-программный комплекс.

\section{APPLICATION OF THE HARDWARE-SOFTWARE BIOFEEDBACK COMPLEXES IN THE REHABILITATION OF PATIENTS WITH VERTEBROLOGY PATHOLOGY}

\author{
O. A. Panchenko, S. M. Radchenko, V. H. Antonov, A. V. Zarubaiko \\ SI "Scientific and Practical Medical Rehabilitation Rehabilitation and Diagnostic Centre \\ of MPH of Ukraine"

\begin{abstract}
The modern aspects of the rehabilitation of patients with pathology of musculoskeletal system with use hardware-software complexes are considered. The results of the use of the rehabilitation programs with the application of kinesitherapy for patients with vertebrogenic pathology are analysed. A conclusion ab out efficiency of complexes of this class is done and their more wide use is recommended.
\end{abstract}

Key words: rehabilitation, kinezotherapy, informatisation, rehabilitation equipment, hardware-software complex.

Вступ. Сучасна реабілітація відрізняється високим рівнем інформатизації діагностичних і лікувальних методик, впровадженням нових засобів діагностики і направленого зовнішнього впливу на організм (реабілітаційне устаткування, апаратно-програмні комплекси), що базуються на передових технологіях кібернетики, мікропроцесорної техніки, програму- вання тощо. У всіх цих системах на першому місці стоять завдання точного дозування параметрів роботи, стабільного утримання їх заданих значень в умовах мінливості фізіологічних характеристик організму пацієнта.

Особливої уваги заслуговують комплекси з біологічним зворотним зв'язком, робота яких направлена

(C) О. А. Панченко, С. М. Радченко, В. Г. Антонов, А. В. Зарубайко 
на розвиток та вдосконалення механізмів саморегуляції фізіологічних функцій при різних патологічних станах. Поки що такі комплекси в реабілітаційних закладах України застосовуються мало, тому досвід роботи з ними та доведення на практиці їх ефективності мають велике значення для популяризації цього безперечно перспективного методу реабілітації.

Мета роботи - дослідження ефективності реабілітації хворих із вертеброгенними захворюваннями iз застосуванням багатофункціонального апаратнопрограмного комплексу EN-TгееM.

Матеріали та методи. В дослідженні ефективності застосування реабілітаційних програм взяли участь 269 осіб - 73 чоловіки та 196 жінок (табл. 1), які знаходилися на відновлювальному лікуванні в Д3 «НПМ РДЦ МО3 України» 3 вертеброгенними порушеннями (М 42.0-М 54 за МКБ-10) в ступені загострення.

Таблиця 1. Характеристика обстежуваного контингенту

\begin{tabular}{|c|c|c|c|c|c|}
\hline \multirow{2}{*}{ Стать пацієнтів } & \multirow{2}{*}{$\begin{array}{c}\text { Вік, років } \\
(\text { Ме } \pm \text { m) }\end{array}$} & \multicolumn{2}{|c|}{ Кількість обстежених } & \multicolumn{2}{|c|}{ Кількість сеансів реабілітації } \\
\cline { 3 - 6 } & $53 \pm 1,8$ & абс. & $\%$ & абс. & \% \\
\hline Чоловіки & $52 \pm 1,6$ & 196 & 73,9 & 2461 & 59,8 \\
\hline Жінки & 269 & 100 & 4117 & 100 \\
\hline \multicolumn{2}{|c|}{ Загальна кількість } &
\end{tabular}

Водночас із лікуванням за клінічним протоколом надання медичної допомоги хворим на дорсопатію (наказ МО3 України від 17.08.2007 року № 487) хворим було запропоновано реабілітаційне лікування за оригінальною методикою із застосуванням багатофункціонального апаратно-програмного комплексу EN-TreeM.
Зовнішній огляд, опитування пацієнтів на наявність скарг на поточний стан здоров'я та аналіз їх амбулаторних карт дали можливість виділити осіб з дорсопатіями (178 осіб, середній вік $(51 \pm 1,7)$ рік) та плексопатіями (91 особа, середній вік - $(55 \pm 1,6)$ років). Характеристика досліджуваного контингенту представлена в таблиці 2.

Таблиця 2. Характеристика контингенту, поділеного за діагнозом

\begin{tabular}{|c|c|c|c|c|c|}
\hline \multirow{2}{*}{ Діагноз пацієнтів } & \multirow{2}{*}{$\begin{array}{c}\text { Вік, років } \\
(\mathrm{Me} \pm \mathrm{m})\end{array}$} & \multicolumn{2}{|c|}{ Кількість обстежених } & \multicolumn{2}{|c|}{ Кількість сеансів реабілітації } \\
\cline { 3 - 6 } & $51 \pm 1,7$ & абс. & $\%$ & абс. & 76,1 \\
\hline Дорсопатії & $55 \pm 1,6$ & 91 & 33,8 & 983 & 23,9 \\
\hline Плексопатії & 269 & 100 & 4117 & 100 \\
\hline \multicolumn{2}{|c|}{ Загальна кількість } &
\end{tabular}

У пацієнтів із дорсопатіями домінували больовий та м'язовотонічний синдроми, а у осіб із плексопатіями, крім вищезазначених, виявлявся корінцевий синдром. Пацієнти скаржилися на біль в попереку, обмеження рухів, які посилювалися при поворотах тулуба, напруження м'язів. Пацієнти обох груп проходили стандартне лікування, яке включало нестероїдну протизапальну, вітамінотерапію, міорелаксаційну, хондропротекторну терапію.

Для оцінки стану організму пацієнтів до початку і після курсу лікування проводилися наступні методи: збір анамнезу, об'єктивне дослідження, антропометричні дані.

Оцінка стану нервово-м'язового апарату проводилася за даними електроміографії (ЕМГ) до та після курсу кінезотерапії за допомогою апарату «МУОМЕБ 932».
Застосовували наступні методи дослідження: дослідження іннервації; проба на збудливість; визначен ня реобази, хронаксії, величини корисного часу по кривій $1 / t$.

Об'єктом дослідження при міографії були м'язи передпліччя правої і лівої руки, круглий пронатор (M. pronator teres), який пронує передпліччя i бере участь в його згинанні. Іннервується N. Medianus від С6-С7.

Для дослідження іннервації проводили порівняння реакції двох симетричних контрлатеральних м'язів або груп м'язів, в одній з яких іннервація, імовірно, порушена.

При проведенні проби на збудливість визначали міру дегенерації в м'язах. Для цього проводили стимуляцію м'яза і визначали відповідь м'яза на подразнення. В ході міографічного дослідження визначали рео- 
базу, хронаксію, по кривій 1/t визначали величину корисного часу.

Всього було проведено 538 досліджень хронаксії.

Кінезотерапія - один із головних режимів роботи тренажера EN-TreeM, проводилася з застосуванням біологічного зворотного зв'язку. Біологічний зворотний зв'язок - технологія, яка включає комплекс дослідницьких, лікувальних і профілактичних фізіологічних процедур, в ході яких пацієнтові за допомогою зовнішнього ланцюга зворотного зв'язку, організованого переважно за допомогою мікропроцесорної або комп'ютерної техніки пред'являється інформація про стан і зміну тих або інших власних фізіологічних процесів. Терапія за цією технологією полягає в безперервному моніторингу в режимі реального часу певних фізіологічних показників і свідомому управлінні ними за допомогою мультимедійних, ігрових та інших прийомів в заданому діапазоні значень. Для стимулювання пацієнта в процесі тренувальної терапії й реабілітації вибирались різні екранні сторінки зворотного зв'язку, оптимальні з точки зору пацієнта.

Отримані результати аналізувалися в статистичних пакетах Statistica 5.5 (StatSoft. Inc., 1999), Statistica Neural Networks 4.0C (StatSoft. Inc., 1999), MedStat 2004.

Результати та їх обговорення. В результаті досліджень встановлено, що вихідні значення сили і витривалості у чоловіків і жінок достовірно відрізнялися $(\mathrm{p}<0,05)$. У жінок початкове середне значення сили складало $(22,0 \pm 0,9)$ (95 \% ВІ 20-24) кгс, у чоловіків - $(44,0 \pm 1,5)$ (95 \% ВI 40-46) кгс. М'язова витривалість у жінок до курсу складала в середньому $(32,5 \pm 2,9)(95 \%$ ВI 30-40) с, у чоловіків - $(45,0 \pm 4,1)$ (95\% ВI 45-50) с (табл. 3).

Таблиця 3. М'язова сила та м'язова витривалість у 1-й день реабілітації, Ме \pm т

\begin{tabular}{|c|c|c|}
\hline Дослідження & $\begin{array}{c}\text { Чоловіки, } \\
\mathrm{n}=73\end{array}$ & $\begin{array}{c}\text { Жінки, } \\
\mathrm{n}=196\end{array}$ \\
\hline М'язова сила, кгс & $44,0 \pm 1,5$ & $22,0 \pm 0,9$ \\
\hline М'язова витривалість, с & $45,0 \pm 4,1$ & $32,5 \pm 2,7$ \\
\hline
\end{tabular}

Вплив разового сеансу кінезотератї характеризувався збільшенням м'язової сили і витривалості у пацієнтів обох статей. Значення сили як у жінок, так і у чоловіків збільшувалися в середньому на 1 (95\% ВI 0-2) кгс $(\mathrm{p}<0,05)$. М'язова витривалість у жінок змінювалася в середньому на 2 (95 \% ВI 1-3) с, у чоловіків на 1 (95 \% ВI 0-4) c $(\mathrm{p}<0,05)$. Ці зміни говорять про стимулювальний вплив кінезотерапії на організм людини, який покращує функціональний стан нервово-м'язового апарату.
Впливу всього курсу реабілітації на значення показників сили у жінок виявлено не було, у чоловіків сила збільшилась в середньому до $(45,5 \pm 2,7)(\mathrm{p}>0,05)$ (табл. 4).

Таблиця 4. М'язова сила та м'язова витривалість на 20-й день реабілітації, Ме \pm т

\begin{tabular}{|c|c|c|}
\hline Дослідження & $\begin{array}{c}\text { Чоловіки, } \\
\mathrm{n}=73\end{array}$ & $\begin{array}{c}\text { Жінки, } \\
\mathrm{n}=196\end{array}$ \\
\hline М'язова сила, кгс & $45,5 \pm 2,7$ & $22,5 \pm 0,9$ \\
\hline М'язова витривалість, с & $50,0 \pm 1,7$ & $33,2 \pm 1,6$ \\
\hline
\end{tabular}

Після курсу реабілітації у чоловіків витривалість збільшилася в середньому на 5 (95 \% ДІ 2-6) с і складала $(50 \pm 1,7)(95 \%$ ВI 49-55) с $(\mathrm{p}<0,05)$, у жінок витривалість практично залишилася на колишньому рівні $(33,2 \pm 1,6)(95 \%$ ВI 36-47) с ( $>>0,05)$.

В процесі дослідження було проведено дослідження хронаксії. Вихідні значення хронаксії у жінок скла-

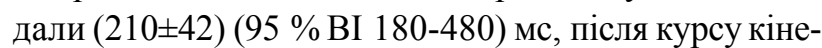
зотерапії - (212士46) (95 \% ВI 150-400) мс, ці значення статистично між собою не відрізнялися $(\mathrm{p}>0,05)$ (табл. 5).

Таблиця 5. Динаміка показників хронаксії в результаті курсу реабілітації, $\mathrm{Me} \pm \mathrm{T}$

\begin{tabular}{|c|c|c|}
\hline \multirow{2}{*}{ Дні реабілітації } & \multicolumn{2}{|c|}{ Хронаксія, мс } \\
\cline { 2 - 3 } & $\begin{array}{c}\text { чоловіки, } \\
\mathrm{n}=73\end{array}$ & $\begin{array}{c}\text { жінки, } \\
\mathrm{n}=196\end{array}$ \\
\hline 1 -й день & $200 \pm 35$ & $210 \pm 42$ \\
\hline 20 -й день & $130 \pm 61$ & $200 \pm 46$ \\
\hline
\end{tabular}

У чоловіків середнє значення хронаксії до курсу

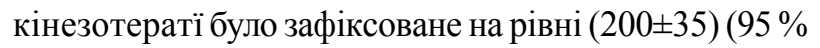

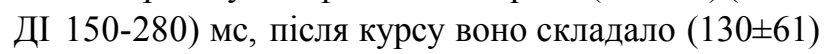
(95 \% ДІ 100-300) мс $(\mathrm{p}<0,05)$. Таким чином, курс реабілітації впливав на показники лише у чоловіків.

Клінічні спостереження продемонстрували хорошу переносимість кінезотерапії та відсутність негативних реакцій. Всі хворі відзначали зменшення вихідного болю і легше виконували фізичні вправи. Поліпшення наставало вже після перших процедур.

Після курсу реабілітації спостерігалося значуще зниження болю, запалення аж до повного купірування больового синдрому і деструктивних запальних реакцій, збільшення об'єму рухів. Термін купірування вертеброгенного больового синдрому склав 2-5 днів, корінцевого - 4-12 днів. Оцінка інтенсивності болю здійснювалась 3 використанням Verbal Descriptor Scale - VDS (GastonJohansson F., Albert M., Fagan E. et al., 1990) до та після закінчення курсу реабілітації. Виявлено ста- 
тистично значуще зниження больового синдрому $(\mathrm{p}<0,05)$ (табл. 6).

3 клінічних проявів на 1-й день кінезотерапії у пацієнтів мали місце: больовий синдром - у 260 осіб (97\%), оніміння тильної поверхні стопи - у 182 осіб $(67,5 \%)$, слабкість розгинання 1 пальця стопи - у 60 осіб (22,5 \%), кульгавість - у 54 осіб (20\%), зниження ахілових рефлексів - у 25 осіб (9\%).

Таблиця 6. Динаміка середніх показників інтенсивності болю за шкалою УБ8, Mе \pm т

\begin{tabular}{|c|c|c|}
\hline \multirow{2}{*}{ Дні кінезотерапії } & \multicolumn{2}{|c|}{ Інтенсивність болю, бали } \\
\cline { 2 - 3 } & чоловіки, $\mathrm{n}=73$ & жінки, $\mathrm{n}=196$ \\
\hline 1 -й день & $4,6 \pm 1,6$ & $4,2 \pm 1,0$ \\
\hline 20 -й день & $2,1 \pm 0,8$ & $1,8 \pm 0,4$ \\
\hline
\end{tabular}

Критеріями якості лікування хворих із патологією опорно-рухового апарату стали: зменшення або зникнення больового синдрому чи корінцевих проявів; збільшення обсягу рухів в ураженому відділі; покращення самопочуття; клінічне одужання або поліпшення.

В результаті проведеного лікування 100 \% пацієнтів iз дорсопатіями та плексопатіями були виписані з поліпшенням. Спостерігалось помітне зменшення больового синдрому, зникли прояви оніміння тильної поверхні стопи, слабкості розгинання 1 пальця стопи, кульгавість, знизились ахіллові рефлекси $(\mathrm{p}<0,05)$.

Випадків погіршення стану хворих в процесі лікування не відмічено, побічних ефектів і ускладнень при проведенні процедур не спостерігалося.

Висновки. 1. Вплив окремо взятого сеансу кінезотерапії у хворих із вертеброгенною патологією характеризувався збільшенням м'язової сили та витривалості у пацієнтів обох статей. Це свідчить про стимулюючий вплив сеансу кінезотерапії на організм

\section{Література}

1. Биоуправление в клинической практике / М. Б. Штарк, С. С. Павленко, А. Б. Скок, О. С. Шубина // Неврологічний журнал - 2000. - № 5. - С. 52-56.

2. Мінцер О. П. Проблеми виявлення нових знань із сховищ медичних даних. Перше повідомлення / О. П. Мінцер, С. В. Денисенко, Л. Ю. Бабінцева // Медична інформатика та інженерія. - 2012. - № 2. - С. 5-10.

3. Панченко О. А. Информатизация реабилитационно-диагностического процесса в современных медицинских учреждениях / О. А. Панченко, А. Н. Пономаренко, А. Е. Горбань [и др.] // Реабилитациия и абилитация человека. Клиническая иинформационная проблематика: сб. научн. работ / под общ. ред. О. А. Панченко. - К. : КВИЦ, 2012. - С. 175-189.

4. Соколов А. В. Современные направления и перспективы развития аппаратных средств биоуправления / людини, який покращує функціональний стан нервово-м'язового апарату. Значення сили і у жінок, і у чоловіків у результаті сеансу кінезотерапії збільшувалися в середньому на 1 (95 \% ВI 0; 2) кгс (p<0,05); м'язова витривалість у жінок змінювалася в середньому на 2 (95 \% BI 1; 3) с, у чоловіків - на 1 (95\% ВI $0 ; 4)$ с $(\mathrm{p}<0,05)$. Після курсу реабілітації виявлено збільшення м'язової витривалості у чоловіків у середньому на 4 (95 \% ДІ 2; 6) с, у жінок статистично достовірних відмінностей параметрів витривалості до і після курсу зафіксовано не було.

2. Міографічні дослідження показали, що значення хронаксії в результаті курсу кінезотерапії у жінок залишалися стабільними, а у чоловіків змінювалися на

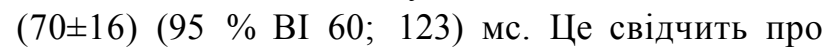
лабільність м'язового тонусу у чоловіків, обумовлену високою питомою часткою поперечносмугастих м'язів.

3. Клінічні спостереження продемонстрували хорошу переносимість процедур кінезотерапії і відсутність негативних реакцій. Всі хворі відзначали зменшення вихідного болю і полегшення виконання фізичних вправ. Поліпшення наставало вже після перших процедур. Після курсу реабілітації спостерігалося значуще зниження болю та запалення аж до повного купірування больового синдрому і деструктивних запальних реакцій, збільшення об'єму рухів. Термін купірування вертеброгенного больового синдрому склав 2-5 днів, корінцевого - 4-12 днів.

4. Використання програмно-апаратних комплексів в реабілітації хворих 3 вертеброгенною патологією дозволяє досягнути ії високої ефективності. Перспективним є подальше дослідження ефективності застосування даного класу комплексів у реабілітації хворих з іншими патологіями.

А. В. Соколов // Медицинская техника. - 2007. - № 4. C. $39-41$.

5. Основы компьютерной биостатистики: анализ информации в биологии, медицине и фармации статистическим пакетом «MedStat» / Ю. Е. Лях, В. Г. Гурьянов, В. Н. Хоменко, О. А. Панченко. - Донецк : Папакица Е. К., 2006. $214 \mathrm{c}$.

6. Glinkowski W. Musculoskeletal 3G telerehabilitation / W. Glinkowski, M. Wasilewska, M. Gil [et al.] // Український журнал телемедицини та медичної телематики. - 2007. - Т. 5 , № 2. - P. 189-190.

7. Web-Based Telerehabilitation for the Upper Extremity After Stroke / D. Reinkensmeyer, C. Pang, J. Nessler, C. Painter // IEEE Transactions on Neural Systems and Rehabilitation Engineering. - 2002. - Vol. 10, № 2. - P 102-108. 